\title{
Emphysematous pancreatitis: classic findings
}

\author{
Ankit Balani, ${ }^{1}$ Amit Kumar Dey, ${ }^{2}$ Sandhya Sarjare, ${ }^{1}$ Chinky Chatur ${ }^{1}$
}

${ }^{1}$ Yashoda Super Specialty Hospitals, Secunderabad, Telangana, India

${ }^{2}$ Seth GS Medical College and KEM Hospital, Mumbai, Maharashtra, India

\section{Correspondence to}

Dr Amit Kumar Dey, amit5kem@gmail.com

Accepted 1 December 2016

CrossMark

To cite: Balani A, Dey AK, Sarjare $\mathrm{S}$, et al. BMJ Case Rep Published online:

[please include Day Month

Year] doi:10.1136/bcr-2016217445

\section{DESCRIPTION}

A 55-year-old man with diabetes presented to our hospital with recent onset acute abdominal pain and recurrent vomiting. He was immediately admitted to the intensive care unit for ionotropic and invasive respiratory support. He had an acutely
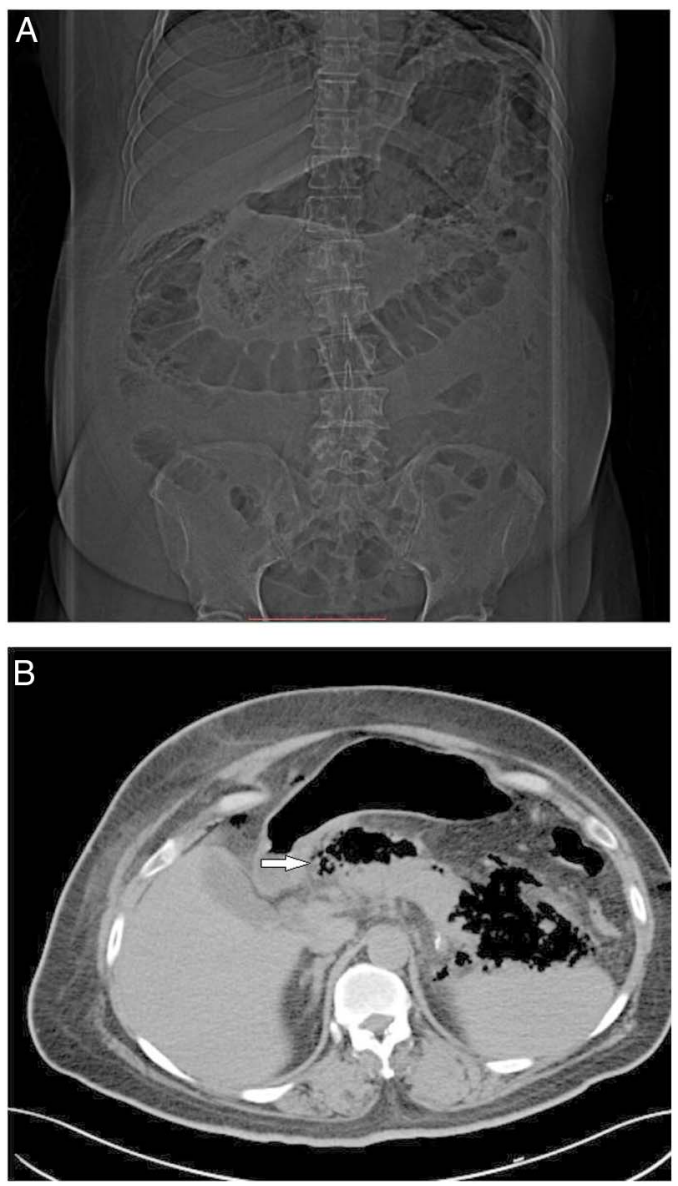

Figure 1 (A) CT image showing the presence of air lucencies in the epigastric region at the level of L1-L2 vertebral bodies, likely emphysematous pancreatitis. (B) Axial non-enhanced CT of the abdomen at the level of pancreas showing intraparenchymal air foci in the region of pancreatic head, body and tail (arrow) extending into the lesser sac and adjacent retroperitoneal space. tender abdomen with distension. Haematological examination showed leucopenia $\left(880 / \mathrm{mm}^{3}\right)$, thrombocytopenia $\left(64000 / \mathrm{mm}^{3}\right)$, elevated $\mathrm{C}$ reactive protein $(68 \mathrm{mg} / \mathrm{mL})$, metabolic acidosis $(\mathrm{pH}$ : 6.88) with a severely elevated blood lactate $(14 \mathrm{mmol} / \mathrm{L})$, estimated creatinine clearance $<14 \mathrm{~mL} / \mathrm{min}$, hyperlipidaemia $(1280 \mathrm{U} / \mathrm{L})$ and serum amylase levels of $5134 \mathrm{U} / \mathrm{L}$. Plain CT revealed extensive gas in the pancreatic bed extending into the lesser sac and adjacent retroperitoneal space (figure 1A, B). A diagnosis of acute severe emphysematous pancreatitis was made; although the patient was aggressively treated, unfortunately he died. Retrospective blood cultures were positive for Enterobacter aerogenes.

\section{Learning points}

- Pancreatic bed gas typically arises from polymicrobial infections due to gas-forming organisms, such as Enterobacteriaceae or anaerobes.

- It can also reflect fistulous communication between the pancreas and digestive tract. ${ }^{1}$

- Emphysematous pancreatitis due to infection of pancreatic necrosis is an extremely severe condition and has a high mortality.

Contributors $A B$ contributed to conception and design, acquisition of data or analysis and interpretation of data. AKD and CC involved in drafting the article or revising it critically for important intellectual content. SS provided final approval of the version published and critical revisions. All authors agree to be accountable for the article and to ensure that all questions regarding the accuracy or integrity of the article are investigated and resolved.

Competing interests None declared.

Patient consent Obtained.

Provenance and peer review Not commissioned; externally peer reviewed.

\section{REFERENCE}

1 Hamada S, Shime N. Emphysematous pancreatitis. Intensive Care Med 2016;42:1075. 
Copyright 2016 BMJ Publishing Group. All rights reserved. For permission to reuse any of this content visit http://group.bmj.com/group/rights-licensing/permissions.

BMJ Case Report Fellows may re-use this article for personal use and teaching without any further permission.

Become a Fellow of BMJ Case Reports today and you can:

- Submit as many cases as you like

- Enjoy fast sympathetic peer review and rapid publication of accepted articles

- Access all the published articles

Re-use any of the published material for personal use and teaching without further permission

For information on Institutional Fellowships contact consortiasales@bmjgroup.com

Visit casereports.bmj.com for more articles like this and to become a Fellow 